Електронне наукове фахове видання «Адаптивне управління: теорія і практика. Серія «Педагогіка»

УДК 378.14

https://doi.org/10.33296/2707-0255-9(17)-13

http: //orcid0000-0002-4321-0900

НАТАЛІЯ МАЛАНЮК

кандидат педагогічних наук, викладач циклової комісії загальноосвітніх дисциплін, Київський коледж транспортної інфраструктури, м. Київ, Україна

\title{
РОЛЬ МОТИВАЦІЇ В ПРОФЕСІЙНІЙ ПІДГОТОВЦІ МАЙБУТНІХ ФАХІВЦІВ ЗАЛІЗНИЧНОГО ТРАНСПОРТУ
}

Анотація. У статті з'ясовано та досліджено роль мотивації в професійній підготовці майбутніх фахівців залізничного транспорту. Уточнено дефініції «мотив», «потреба», «мотивація». 3'ясовано ієрархію понять потреба-мотивмотивація. Досліджено, що мотив особистості тісно пов'язаний із спрямованістю особистості на діяльність та на ступінь проявів активності в ній. 3'ясовано роль потреб в діяльності людини. Потреба виступає каталізатором поведінкової активності людини. Саме потреби керують мисленням, почуттями, емоціями тощо. Наявність в особистості потреб визначають низку цілей, які ставить перед собою особистість. Для досягнення поставлених цілей, пов'язаних із потребами особистості, індивіду необхідно обрати мотиви. Розглянуто ієрархічні рівні потреб.

Досліджено блоки мотивів: безпосередні та опосередковані. Розглянуто різні класифікації мотивів: зовнішні і внутрішні; потенційні та актуальні.

3'ясовано, що на освітньо-професійну діяльність студентів здійснюють вплив три групи мотивів: безпосередньо-спонукальні мотиви базуються на емоціях (негативних чи позитивних); перспективно-спонукальні - престиж спеціальності; інтелектуально-спонукальні - задоволення від самого процесу пізнання, прагнення до саморозвитку.

Виокремлено функції мотивів у професійній підготовці майбутніх фахівців залізничного транспорту. З'ясовано причини низької успішності студентів в освітній діяльності.

Проведено анкетування студентів-першокурсників коледжу 3 метою виявлення причин низької успішності. Отримані результати анкетування стали підгрунтям для вдосконалення освітнього процесу і пошуку шляхів покращення результатів навчання (індивідуальні та групові консультації; робота над формуванням навичок самостійної діяльності та планування часу на виконання домашніх завдань; інноваційні технології навчання, спрямовані на зацікавленість освітнім матеріалом, практична направленість навчальних курсів).

Виявлено та досліджено провідні мотиви освітньої діяльності студентів, а також описано їх динаміку змін за період навчання в коледжі (I - IV курси). 
Ключові слова: мотивація, мотив, потреба, професійна підготовка, майбутні фахівці, залізничний транспорт.

Вступ. Стрімкий розвиток науки й техніки, інформатизація всіх сфер життя та діяльності кожної особистості, входження України в європейський економічний простір - ті фактори, які відіграють ключову у розвитку кожного суспільства на сучасному етапі. 3 іншого боку, саме людиноресурс є рушієм розвитку суспільства. Майбутнє кожної галузі - це конкуренто спроможні фахівці, які здатні розвиватися у мінливостях довколишньої дійсності, а також прагнуть модернізовувати та вдосконалювати сферу своєї професійної діяльності.

Підгрунтям для успішної професійної діяльності є ефективна професійна підготовка, ключовим компонентом якої $є$ мотивація. Це означає, що в майбутніх фахівців потрібно формувати стійку мотивацію спочатку до освітньої діяльності, а потім - і до майбутньої професійної.

Студент не буде успішним в освітньому процесі, якщо він не буде проявляти інтерес до того, що вивчається. Науково доведено, що для ефективності освітнього процесу необхідна активність зі сторони студентів, тобто рівень пізнавальної активності студентів прямо пропорційний одержаному кінцевому результату освітнього процесу, професійної підготовки.

Аналіз останніх досліджень і публікацій. Проблеми мотивації в освітній діяльності $є$ предметом дослідження багатьох науковців: педагогів Ю.Бабанського, С. Занюк, Л. Несух, В. Тернопільської та інші, психологів Є.Ільїна, О.Леонтьєва, А. Маркової, В. Шадрикова, П. Якобсона та інших.

Незважаючи на широке висвітлення проблеми мотивації студентів до освітньої діяльності, залишилися поза увагою деякі практичні моменти щодо формування позитивної мотивації та ціннісних орієнтирів у студентівздобувачів фахової передвищої освіти. Адже мотивація як психологопедагогічний феномен набуває щоразу нових відтінків для кожного наступного покоління студентів. Тому проблема мотивації освітньої діяльності в студентів 
Електронне наукове фахове видання «Адаптивне управління: теорія і практика. Серія «Педагогіка»

- майбутніх фахівців залізничного транспорту є актуальною і потребує пошуків шляхів їі вирішення.

Метою статті $\epsilon$ дослідження мотивації, розкриття іiі характеристик в студентів коледжу - майбутніх фахівців залізничного транспорту та пошук шляхів іï формування.

Виклад основного матеріалу статті. Перш, ніж перейти до викладу теми статті, з’ясуємо сутність категорій дослідження.

Дефініція «мотив» у психологічному словнику І. Войтка трактується так:

- спонукання до діяльності з метою задоволення потреб;

- сукупність умов, що спонукають суб’єкта до спрямованої активності;

- предмет, що спонукає до діяльності;

- усвідомлена причина дій особистості [10, с. 264].

Психолог Л. Виготський наголошував, що «думка виникає не 3 іншої думки, а з мотивуючої сфери свідомості особистості» [1]. Вчений І. Малафіїк стверджує, що мотив - це те, що «спонукає людину до діяльності та надає цій діяльності осмислення» [4].

Науковцями доведено, що мотивація - «опосередкована процесом іiі віддзеркалення суб’єктивна детермінація поведінки людини» [3].

Отже, мотив - це низка зовнішніх та внутрішніх чинників, які зумовлюють активність індивіда та пов'язані із задоволенням його потреб. Аналізуючи визначення мотиву в різних авторів, приходимо до висновку, що мотив тісно пов'язаний із спрямованістю особистості на певну діяльність та ступенем активності в ній.

Дослідниця Н. Лісовець зазначає, що мотивація складається з таких явищ: індивідуальної системи мотивів та динамічності освіти (дії, спрямовані на активізацію мотивів) [2].

Поряд із мотивами психологи розглядають дефініцію «потреба».

Науковець Н. Маркова розглядає потребу як стан особистості, що проявляється відчуттям необхідності чогось важливого для існування або розвитку [6]. 
Електронне наукове фахове видання «Адаптивне управління: теорія і практика. Серія «Педагогіка»

Випуск 9(17), 2020

Потреба виступає каталізатором поведінкової активності людини. Саме потреби керують мисленням, почуттями, емоціями тощо. Наявність в особистості потреб визначають низку цілей, які ставить перед собою особистість. Для досягнення поставлених цілей, пов'язаних із потребами особистості, індивіду необхідно обрати мотиви.

Науковці поділяють потреби особистості на такі групи: біологічні, матеріальні та духовні. Ці групи потреб стають визначальними для мотивів діяльності особистості. Сукупність мотивів формують мотивацію особистості до певної діяльності та спонукають ії до активності [12].

Американський психолог А. Маслоу зобразив потреби людини, враховуючи їх ієрархію [7]. Так звана, піраміда потреб А. Маслоу містить 5 рівнів потреб. Найнижчим (першим) рівнем $є$ задоволення потреб фізіологічних; другим рівнем - потреби безпеки; третім рівнем - соціальні потреби; четвертим рівнем - потреби в повазі (досягнення, компетентності, визнання); п'ятим рівнем - потреба в самореалізації (самовираженні). Психолог відзначив, що спочатку людина намагається задовольнити потреби нижчих рівнів, лише тоді вона може керуватися потребами вищих рівнів.

Дослідниця Л. Несух виокремила два блоки мотивів: безпосередні (включені в саму діяльність) та опосередковані (не належать до діяльності, але нею задовольняються) [9]. До безпосередніх мотивів належать: пізнавальні та мотиви розвитку особистості. До опосередкованих мотивів відносять: соціальні та мотиви досягнення [12].

Дослідник Р. Малінаускас відзначає, що на освітню діяльність студентів чинить вплив одразу низка мотивів: зовнішніх та внутрішніх [5]. Автор наголошує, що зовнішні мотиви можуть бути як позитивними, так i негативними (іноді нейтральні).

Внутрішні мотиви науковці поділяють на дві групи: пізнавальні мотиви та мотиви досягнення [5; 12].

Науковці-психологи, аналізуючи мотиви освітньої діяльності студентів, вказують на такі види мотивів: потенційні та актуальні. Якщо студент проявляє 
Електронне наукове фахове видання «Адаптивне управління: теорія і практика. Серія «Педагогіка»

активність у діяльності, то його потенційні мотиви можуть перейти в актуальні. Це означає, що в процесі діяльності потреба модифікується в установку на діяльність, наміри трансформуються у дії, плани на здійснення діяльності перетворюються на саму діяльність.

Дослідниця В. Тернопільська виокремлює три групи мотивів, які мають вплив на освітньо-професійну діяльність студентів: безпосередньо-спонукальні, перспективно-спонукальні, інтелектуально-спонукальні [11]. Авторка наголошує, що безпосередньо-спонукальні мотиви базуються на емоціях (негативних чи позитивних); перспективно-спонукальні - престиж спеціальності; інтелектуально-спонукальні - задоволення від самого процесу пізнання, прагнення до саморозвитку.

Таким чином, мотивація відіграє важливу роль в кожній людській діяльності. Розглянемо професійну підготовку майбутніх фахівців залізничного транспорту як діяльність (освітня, пізнавальна, професійно-орієнтована тощо). Для того, щоб ефективно здійснювати освітню діяльність, у студента має бути сформована низка мотивів такої діяльності. У кожного студента на момент вступу до коледжу є наявність позитивних (негативних, нейтральних) мотивів щодо освітньої діяльності. Завдання викладачів та психолога коледжу дослідити та оцінити мотиви освітньої діяльності студентів I курсу, допомогти їм вибудовувати низку позитивних мотивів для здійснення освітньої та майбутньої професійної діяльності.

Мотиви в освітній діяльності відіграють центральну функцію, оскільки:

- керують поведінкою студентів;

- впливають на процес і результат освітньої діяльності.

Таким чином, мотивація - це внутрішня рушійна сила особистості, яка спонукає іiі до здійснення діяльності, при чому чим вищий позитивний показник у мотивації, тим ефективніше буде виконана діяльність, на яку вона спрямована. Тому під мотивацією студентів - майбутніх фахівців залізничного транспорту будемо розуміти низку позитивних мотивів, які сприяють активності особистості в освітній діяльності, а також яка $є$ підгрунтям для 
Електронне наукове фахове видання «Адаптивне управління: теорія і практика. Серія «Педагогіка»

формування професійної мотивації (до виконання професійної діяльності). Мотивація майбутніх фахівців залізничного транспорту до діяльності (освітньої, професійної) має особливості, які пов'язані зі специфікою обраної спеціальності: престижність, соціальна орієнтація, династія залізничників тощо. Мотивація у студентів характеризується мінливістю на різних етапах професійної підготовки, що пов'язане 3 розумінням та свідомим вибором майбутньої професії. Саме від відповідності мотиваційної сфери студента залежить його академічна успішність у процесі професійного становлення.

Науковці зазначають, що основними причинами низької успішності студентів в освітньому процесі $є$ такі:

- невідповідність освітньої діяльності професійним інтересам студентів;

- низький рівень освітньої мотивації;

- рівень педагогічної майстерності викладачів [11].

Для того, щоб з'ясувати, якими бачать причини власної неуспішності студенти першого курсу, було проведено анкетування, що містило такі питання:

1. Чи вважаєте Ви свою освітню діяльність успішною?

2. Чи могли б Ви навчатися краще?

3. Яка з перелічених причин неуспішності найбільш вагома для

а) відсутність навичок самостійної діяльності та самоконтролю;

б) відсутність успіху (досвід невдач);

в) нецікаво;

г) лінь;

г) несправджені очікування?

4. Чи влаштовує Вас власна успішність?

5. Чи хотіли б Ви покращити свої освітні результати?

Проаналізуємо одержані відповіді.

Ілюстрації відповідей на запитання анкети подано на рис. 1-5: 
Електронне наукове фахове видання «Адаптивне управління: теорія і практика. Серія «Педагогіка»

1. Чи вважаєте Ви свою освітню діяльність успішною?

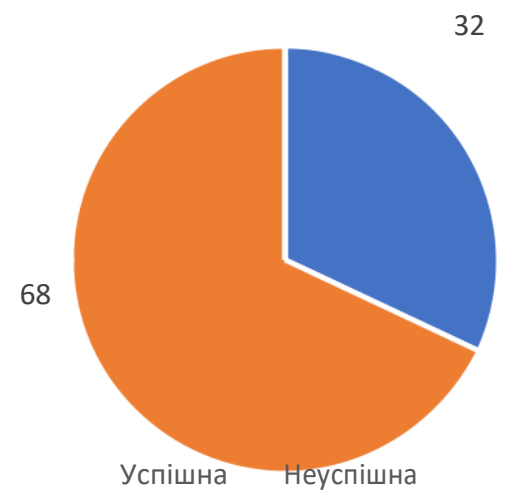

Рис.1. Ілюстрацція відпо̄відей на запитання 1.

Відповіді на питання 1 засвідчили, що лише $32 \%$ з усіх опитаних студентів вважають свою освітню діяльність успішною.

\section{2. Чи могли б Ви навчатися краще?}

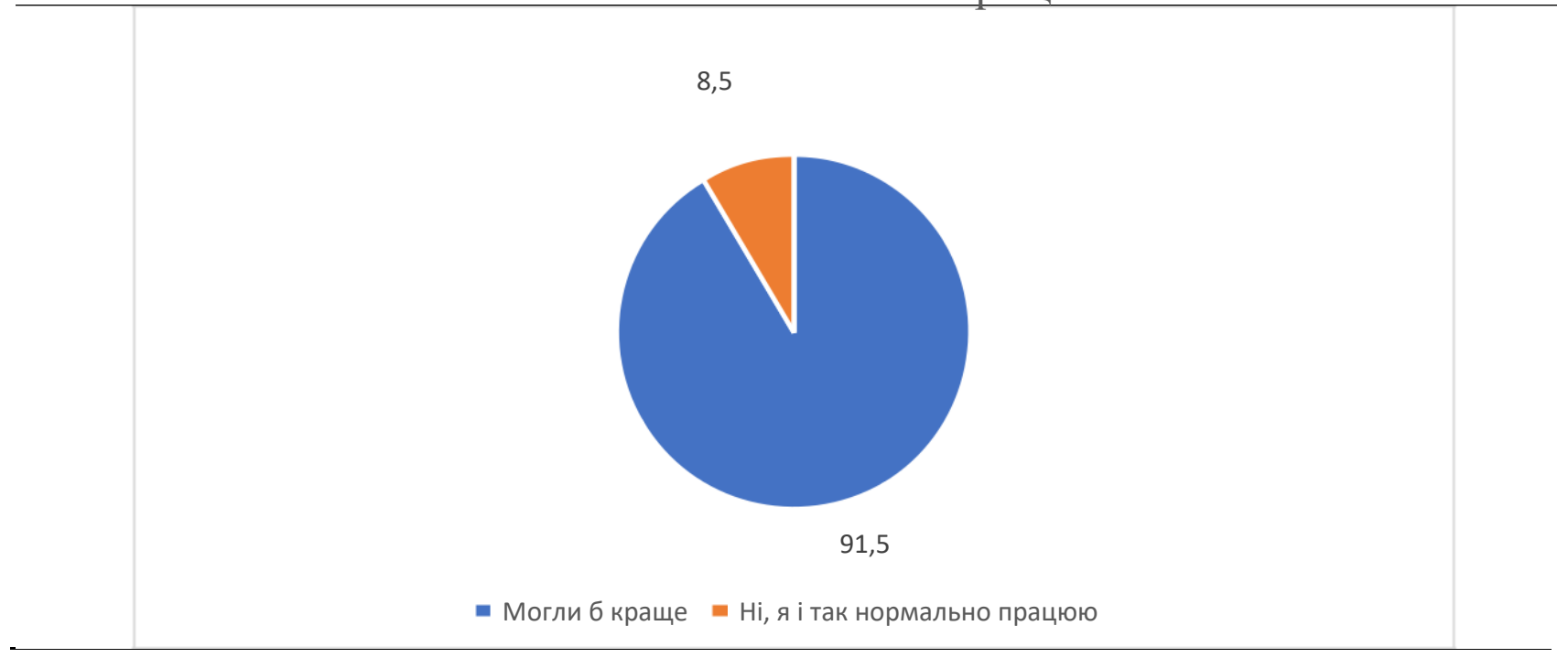

Рис. 2. Ілюстрація відповідей на запитання 2.

Отримані відповіді на запитання 2 вказують на те, що студенти в більшості адекватно оцінюють свою освітню діяльність: 91,5\% студентів переконані, що могли б навчатися краще. 


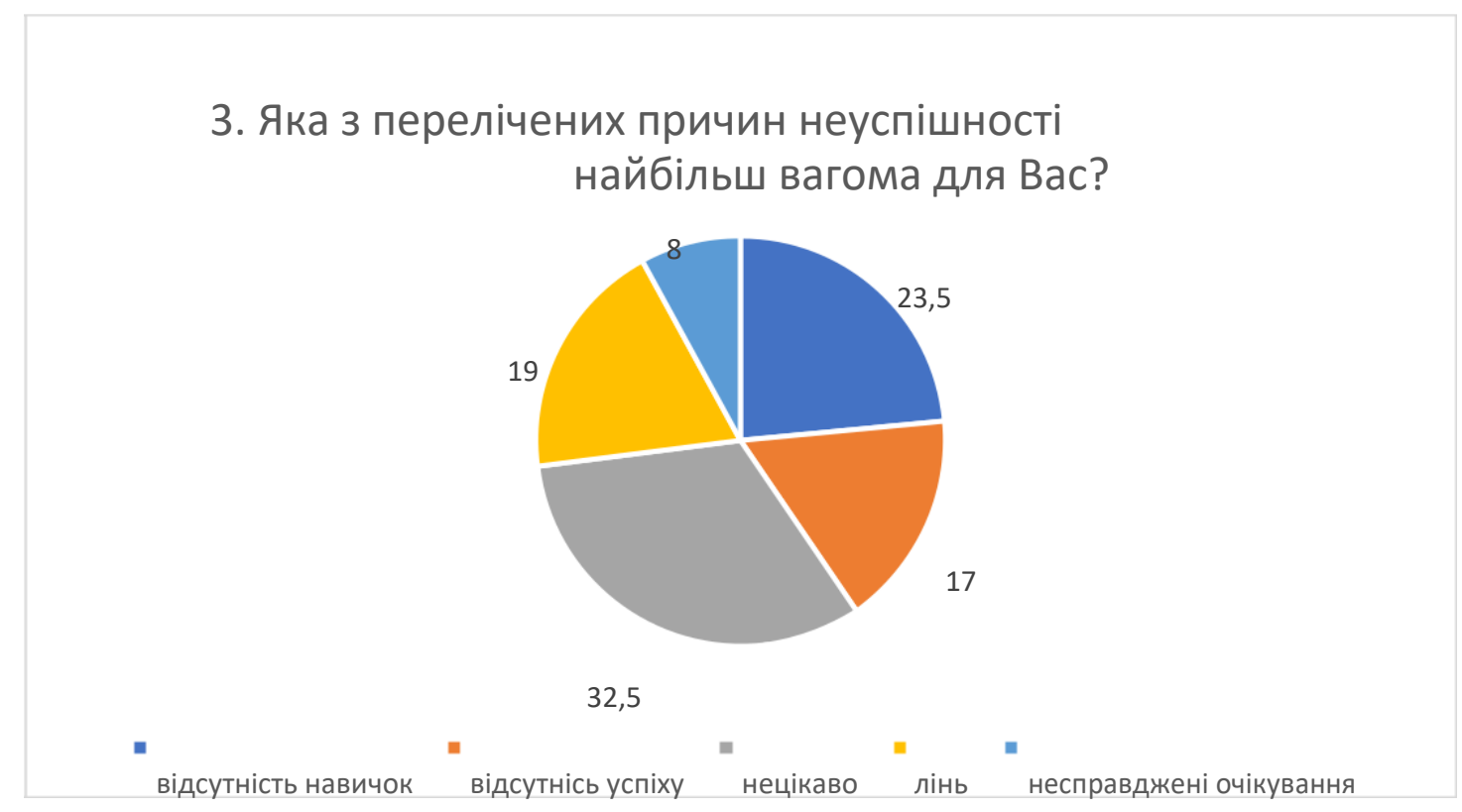

Рис. 3. Ілюстрація відповідей на запитання 3.

Відповіді на це питання були отримані такі: $32,5 \%$ опитаних студентів вважаю, що причиною неуспішності є нецікавий матеріал, виклад тощо; 23,5\% відсутність навичок (хотіли б краще, але не знають, як); 19\% - власну лінь; 17\% - відсутність успіху (не похвалили, не отримав стипендії та інше); 8\% несправджені очікування (по-іншому уявляли освітній процес, освітні дисципліни, вимоги тощо).

4. Чи влаштовує Вас власна успішність?

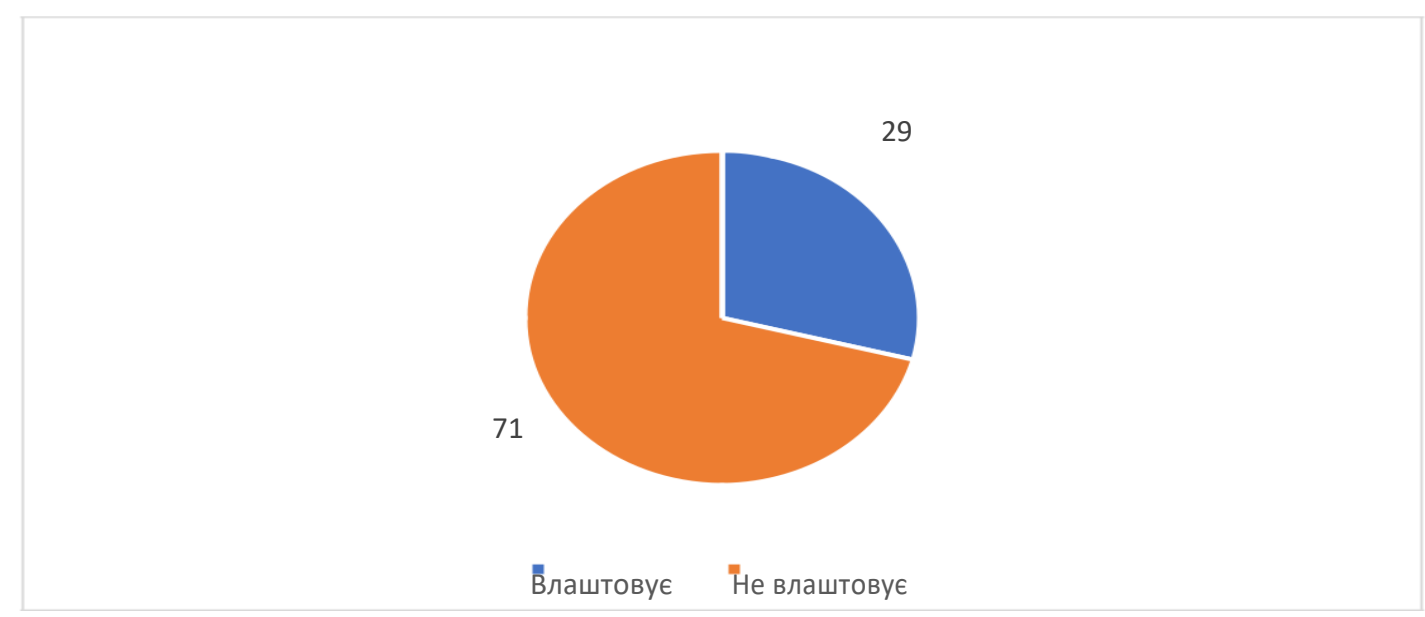

Рис.4. Ілюстрація відповіді на запитання 4. 
Отримані відповіді на запитання 4 засвідчили, що 71\% усіх студентів відчуває незадоволення власною успішністю.

\section{5. Чи хотіли б Ви покращити свої освітні результати?}

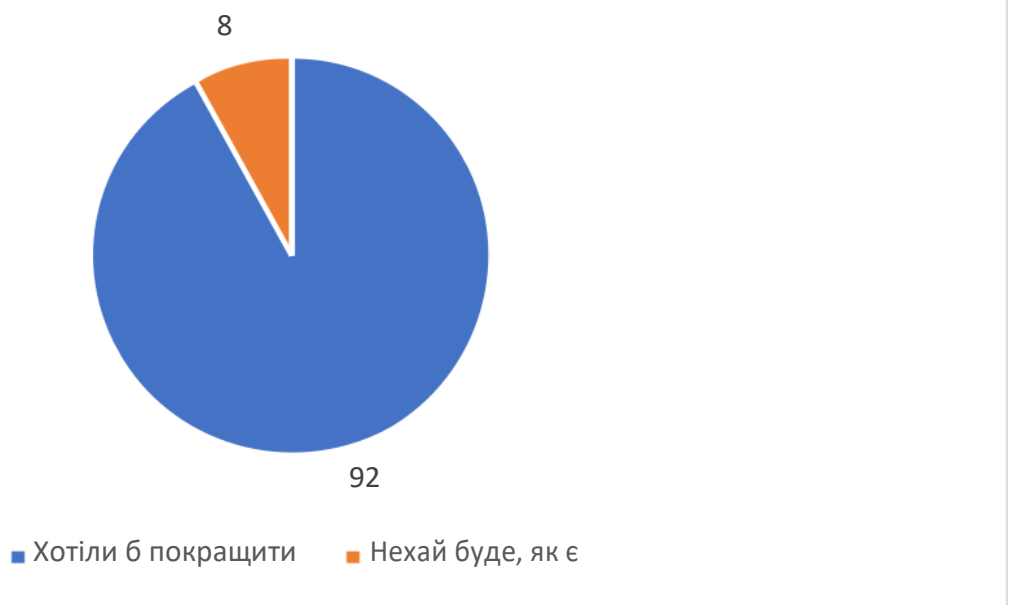

Рис. 5. Ілюстрація відповідей на запитання 5.

Одержані відповіді засвідчили, що студенти в більшості адекватно оцінюють свою освітню діяльність та успішність, а також хотіли б покращити свої результати в освітній діяльності (92\% тих, кого не влаштовує власна успішність).

Також отримані результати анкетування стали підгрунтям для вдосконалення освітнього процесу і пошуку шляхів покращення результатів навчання (індивідуальні та групові консультації; робота над формуванням навичок самостійної діяльності та планування часу на виконання домашніх завдань; інноваційні технології навчання, спрямовані на зацікавленість освітнім матеріалом, практична направленість навчальних курсів тощо).

3 метою виявлення провідних мотивів освітньої діяльності в студентів Київського коледжу транспортної інфраструктури було проведено анкетування студентів I та IV курсів за методикою «Вивчення мотивів навчальної діяльності» (Б. Пашнєва). Ця методика являє собою 28 пар тверджень, через які виявляються вісім мотивів освітньої діяльності. Результати анкетування 
Електронне наукове фахове видання «Адаптивне управління: теорія і практика. Серія «Педагогіка»

оцінюються за допомогою ключа до анкети. Кожна відповідь оцінюється в 1

бал. Мотиви в анкеті позначені літерами:

А - мотив зовнішнього тиску, уникнення покарання;

Б - соціально-орієнтований мотив, що характеризується відчуттям обов'язку та відповідальності;

В - пізнавальний мотив;

Г - мотив престижу;

Д-мотив матеріального добробуту;

Е - мотив отримання інформації;

Ж - мотив досягнення успіху;

3 - мотив оріснтації на соціально-залежну поведінку [8].

Розподіл студентів за мотивами навчальної діяльності подано в табл. 1 (в опитуванні взяли участь студенти I курсу, кількість 127).

Таблиця 1

Розподіл студентів за провідними мотивами навчальної діяльності (I курс)

\begin{tabular}{|c|c|c|c|}
\hline № 3/п & $\begin{array}{c}\text { Мотив } \\
\text { (літера) }\end{array}$ & $\begin{array}{c}\text { Кількість } \\
\text { студентів }\end{array}$ & Відсоток \\
\hline 1 & А & 10 & 8 \\
\hline 2 & Б & 15 & 12 \\
\hline 3 & В & 20 & 16 \\
\hline 4 & Г & 25 & 20 \\
\hline 5 & Д & 36 & 28 \\
\hline 6 & Е & 8 & 6 \\
\hline 7 & Ж & 5 & 4 \\
\hline 8 & 3 & 8 & 6 \\
\hline
\end{tabular}

Результати анкетування засвідчили, що у більшості І-курсників (2016 рік) домінуючим мотивом був мотив Д (матеріального добробуту) - 36 студентів (28\%), а також мотив Г (мотив престижу) - 25 студентів (20\%). Домінуючий пізнавальний мотив (В) було виявлено лише в 20-студентів, що становило $16 \%$ від усіх респондентів. 
Електронне наукове фахове видання «Адаптивне управління: теорія і практика. Серія «Педагогіка»

Розподіл студентів за мотивами навчальної діяльності подано в табл. 2 (в опитуванні взяли участь студенти IV курсу, кількість 125, 2020 рік).

Таблиця 2

Розподіл студентів за провідними мотивами навчальної діяльності

(IV курс)

\begin{tabular}{|c|c|c|c|}
\hline № 3/п & $\begin{array}{c}\text { Мотив } \\
\text { (літера) }\end{array}$ & Кількість студентів & Відсоток \\
\hline 1 & А & 5 & 4 \\
\hline 2 & Б & 7 & 6 \\
\hline 3 & В & 36 & 29 \\
\hline 4 & Г & 25 & 20 \\
\hline 5 & Д & 43 & 34 \\
\hline 6 & $\mathrm{E}$ & 4 & 3 \\
\hline 7 & Ж & 2 & 2 \\
\hline 8 & 3 & 3 & 2 \\
\hline
\end{tabular}

За даними таблиці 2 можна зробити висновок, що домінуючим мотивом для більшості студентів залишається мотив «Д» (матеріального добробуту) $34 \%$, проте відбулося зростання мотиву «В» (пізнавальний мотив) - 29\%.

Динаміка зміни провідних мотивів навчальної діяльності подана на рис.6:

\section{Динаміка зміни мотивів навчальної діяльності}

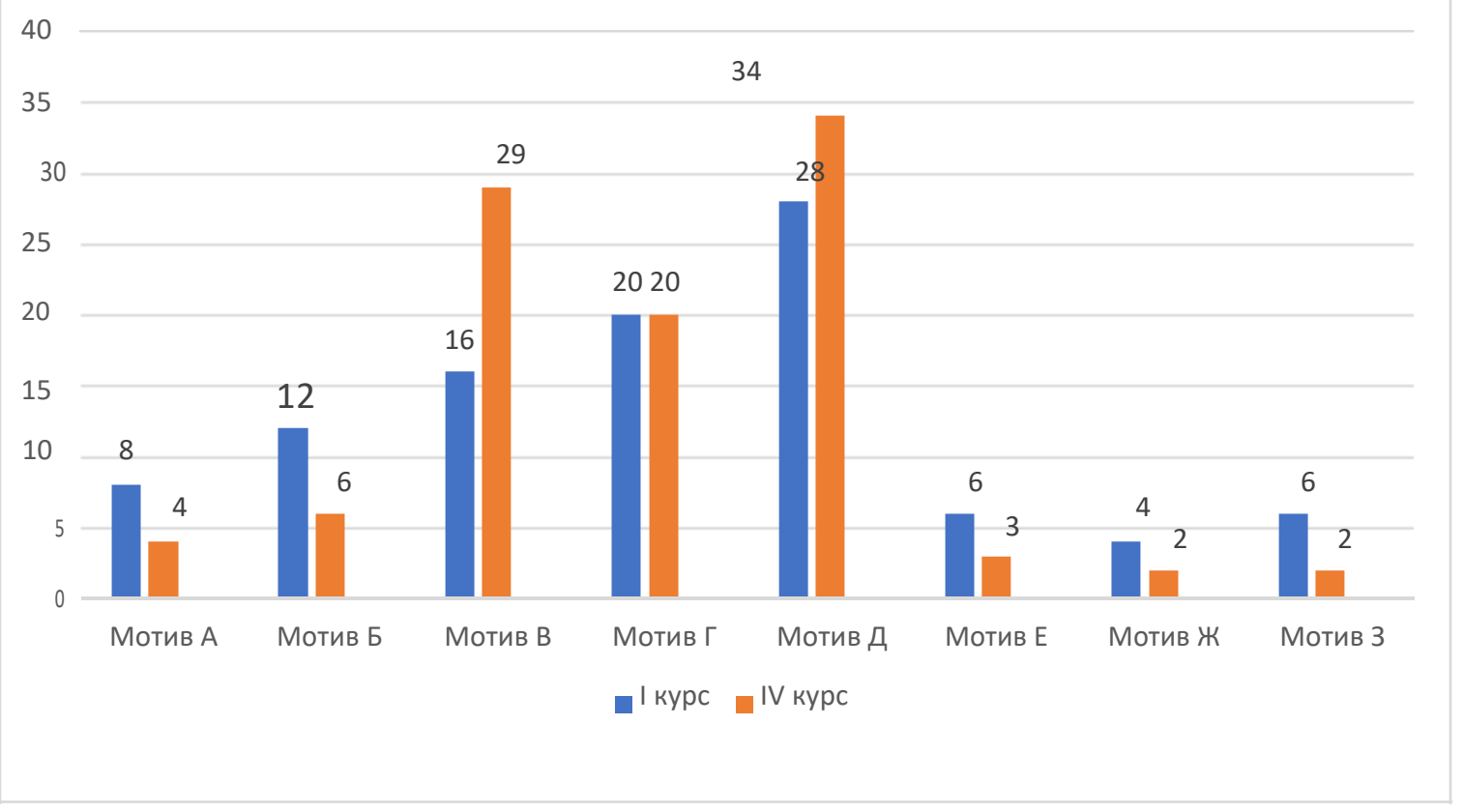

Рис. 6. Динаміка зміни мотивів навальної діяльності 
Проаналізуємо дані з рис.6. За період навчання в коледжі мотив Д (матеріального добробуту) зріс із $28 \%$ до $34 \%$; також зріс мотив В (пізнавальний мотив): із 16\% до 29\%; мотив Г (престижу) залишився незмінним $20 \%$. Зростання пізнавального мотиву свідчить про формування у студентів готовності та здатності до навчання (самоосвіти, саморозвитку), зростання ж мотиву матеріального добробуту свідчить про важливість матеріальної складової у житті, прагнення до добробуту.

Проте зростання пізнавального мотиву як провідного в освітній діяльності студентів потребує пошуків шляхів впливу на процес формування ціннісно-мотиваційних орієнтирів майбутніх фахівців залізничного транспорту.

Висновки. Перспективи подальших досліджень. Отже, мотивація в професійній підготовці майбутніх фахівців залізничного транспорту відіграє важливу роль: впливає на освітній процес та визначає його результат. Проведене дослідження вказало напрямки для подальшої праці 3 метою вдосконалення освітнього процесу та пошуку шляхів підвищення мотивації до освітньої, а також майбутньої професійної діяльності. Наші подальші дослідження будуть спрямовані на пошук оптимального поєднання теоретичного та практичного матеріалу, а також на застосування при вивченні дисциплін математичного циклу інноваційних технологій з метою формування стійкої позитивної мотивації до навчання.

\section{ВИКОРИСТАНІ ДЖЕРЕЛА}

1. Выготский Л. С. Избранные психологические исследования. М.: АПН CCCP, 1956.

2. Лисовец Н. М. Профессиональная мотивация студентов как способ активации обучения. URL: http://www.masters.donntu.edu.ua/ 2012/iem/temnenko/library/ article5.htm.

3. Ляшенко I. В. Формування професійної мотивації студентів до успішної фахової діяльності. Народна освіта. Електронне наукове фахове видання.

URL: https://www.narodnaosvita.kiev.ua/?page_id=1076.

4. Малафіїк І. В. Дидактика. Навчальний посібник. Рівне: РДГУ, 2004. $470 \mathrm{c}$. 
5. Малинаускас Р. К. Мотивация студентов разных периодов бучения. Социологические исследования. 2005. №2. С.134-138.

6. Маркова А. К. Формирование мотивации учения/ А. К. Маркова, Т. А. Матис, А. Б. Орлов. М.: Просвещение, 1990. 138 с.

7. Маслоу А. Мотивация и личность. Санкт-Петербург: Питер, 2002, 478 с.

8. Мотивація навчальної діяльності. Тест (методика Б. Пашнєва). URL: https://sites.google.com/site/ motivacianavcalnoiedialnostis/test.

9. Несух Л. Вплив мотивації на якість навчання студентів. URL: https://ird.npu.edu.ua/files/nesyx.pdf.

10.Психологічний словник/ за ред. В. І. Войтка. К.: Вища школа, 1992. 216 с.

11. Тернопільська В. І. Сучасні тенденції мотивації навчально-професійної діяльності студентів. URL: https://Vnaou_2012_5_30.pdf.

12. Якобсон П. М. Психологические проблемы мотивации поведения человека. М.: А.С.К., 2001. 64 с.

\section{REFERENCES} 1956.

1. Vygotskij L. S. Izbrannye psihologicheskie issledovanija. M.: APN SSSR,

2. Lisovec N. M. Professional'naja motivacija studentov kak sposob aktivacii obuchenija. URL:http://www.masters.donntu.edu.ua/2012/iem/temnenko/ library/ article5.htm.

3. Liashenko I. V. Formuvannia profesiinoi motyvatsii studentiv do uspishnoi fakhovoi diialnosti. Narodna osvita. Elektronne naukove fakhove vydannia. URL: https://www.narodnaosvita.kiev.ua/?page_id=1076.

4. Malafiik I. V. Dydaktyka. Navchalnyi posibnyk. Rivne: RDHU, 2004. 470 s.

5. Malinauskas R. K. Motivacija studentov raznyh periodov obuchenija. Sociologicheskie issledovanija. 2005. №2. S.134-138.

6. Markova A. K. Formirovanie motivacii uchenija/ A. K. Markova, T. A. Matis, A. B. Orlov. M.: Prosveshhenie, 1990. 138 s.

7. Maslou A. Motivacija i lichnost'. Sankt-Peterburg: Piter, 2002, 478 s.

8. Motyvatsiia navchalnoi diialnosti. Test (metodyka B. Pashnieva). URL:https://sites.google.com/site/motivacianavcalnoi edialnostis/test.

9. Nesukh L. Vplyv motyvatsii na yakist navchannia studentiv. URL: https://ird.npu.edu.ua/files/nesyx.pdf.

10. Psykholohichnyi slovnyk/ za red. V. I. Voitka. K.: Vyshcha shkola, 1992.

$216 \mathrm{~s}$.

11. Ternopilska V. I. Suchasni tendentsii motyvatsii navchalno-profesiinoi diialnosti studentiv. URL: https://Vnaou_2012_5_30.pdf.

12. Iakobson P. M. Psykholohycheskye problemb motyvatsyy povedenyia cheloveka. M.: A.S.K., 2001. 64 s. 


\title{
НАТАЛЬЯ МАЛАНЮК
}

кандидат педагогических наук, преподаватель цикловой комиссии общеобразовательных дисциплин, Киевский колледж транспортной инфраструктуры, г. Киев, Украина

\section{РОЛЬ МОТИВАЦИИ В ПРОФЕССИОНАЛЬНОЙ ПОДГОТОВКЕ БУДУЩИХ СПЕЦИАЛИСТОВ ЖЕЛЕЗНОДОРОЖНОГО ТРАНСПОРТА}

\begin{abstract}
Аннотация. В статье выяснено и исследована роль мотивации в профессиональной подготовке будущих специалистов железнодорожного транспорта. Уточнение дефиниции «мотив», «потребность», «мотивация». Выяснено иерархию понятий потребность-мотив-мотивация. Доказано, что мотив личности тесно связан с направленностью личности на деятельность и на степень проявлений активности в ней. Выяснена роль потребностей в деятельности человека. Потребность выступает катализатором поведенческой активности человека. Именно потребности управляют мышлением, чувствами, эмоциями и т. Наличие в личности потребностей определяют ряд целей, которые ставит перед собой личность. Для достижения поставленных целей, связанных с потребностями личности, индивиду необходимо выбрать мотивы. Рассмотрены иерархические уровни потребностей.
\end{abstract}

Исследована блоки мотивов: непосредственные и опосредованные. Рассмотрены различные классификации мотивов: внешние и внутренние; потенциальные и актуальные.

Выяснено, что на образовательно-профессиональной деятельности студентов оказывают влияние три группы мотивов: непосредственнопобудительные мотивы базируются на эмоциях (отрицательных или положительных) перспективно-побудительные - престиж специальности; интеллектуально-побудительные - удовольствие от самого процесса познания, стремление к саморазвитию.

Выделены функции мотивов в профессиональной подготовке будущих специалистов железнодорожного транспорта. Выяснены причины низкой успеваемости студентов в образовательной деятельности.

Проведено анкетирование студентов-первокурсников колледжа с целью выявления причин низкой успеваемости. Полученные результаты анкетирования стали основой для совершенствования образовательного процесса и поиска путей улучшения результатов обучения (индивидуальные и групповые консультации, работа над формированием навыков самостоятельной деятельности и планирования времени на выполнение домашних заданий; инновационные технологии обучения, направленные на заинтересованность образовательным материалом, практическая направленность учебных курсов и 
Т.П. ).

Обнаружены и исследованы ведущие мотивы образовательной деятельности студентов, а также описано их динамику изменений за период обучения в колледже (I - IV курсы).

Ключевые слова: мотивация, мотив, потребность, профессиональная подготовка, будущие специалисты, железнодорожный транспорт.

\author{
NATALIA MALANIUK \\ PhD (Pedagogical Science), \\ Lecturer of the Cycle \\ Commission of General Education \\ Disciplines of the Kyiv College of \\ Transport Infrastructure, \\ Kyiv, Ukraine
}

\title{
THE ROLE OF MOTIVATION IN THE PROFESSIONAL TRAINING OF FUTURE RAILWAY SPECIALISTS
}

\begin{abstract}
The article clarifies and explores the role of motivation in the training of future railway transport specialists. The definitions of "motive", "need", "motivation" have been clarified. The hierarchy of the concepts need-motivemotivation is clarified. It is investigated that the motive of the personality is closely connected with the orientation of the individual to the activity and the degree of manifestations of activity in it. The role of human needs is clarified. Need acts as a catalyst for human behavioral activity. It is needs that control thinking, feelings, emotions, and so on. The presence of needs in the individual determines a number goals that the individual sets for himself. In order to achieve the set goals related to the needs of the individual, the individual must choose the motives. Hierarchical levels of needs are considered.

Blocks of motives are studied: direct and indirect. Different classifications of motives are considered: external and internal; potential and relevant.

It was found that the educational and professional activities of students are influenced by three groups of motives: direct-motivational motives are based on emotions (negative or positive); promising and motivating - the prestige of the specialty; intellectually motivating - satisfaction from the very process of cognition, the desire for self-development.

The functions of motives in the professional training of future railway transport specialists are highlighted. The reasons for students' low academic performance have been identified.

A survey of first-year college students was conducted to identify the reasons for low performance. The results of the questionnaire became the basis for improving the educational process and finding ways to improve learning outcomes (individual and group consultations; work on developing skills of independent activity and time planning for homework; innovative learning technologies aimed at interest in educational material, practical orientation of training courses, etc. ).
\end{abstract}


Електронне наукове фахове видання «Адаптивне управління: теорія і практика. Серія «Педагогіка»

The leading motives of students' educational activity are revealed and researched, as well as their dynamics of changes during the period of study at the college (I - IV courses) is described.

Key words: motivation, motive, need, professional training, future specialists, railway transport. 